\title{
On Pornography and Its Impact on Sexual Violence
}

\author{
ŠIMUN BILOKAPIĆ* - ANA JELIČIĆ ${ }^{* *}$ \\ - https://doi.org/10.31823/d.29.3.8 • \\ UDK: 176.8:364.54 • Review Article \\ Received: $11^{\text {th }}$ November 2020 • Accepted: $24^{\text {th }}$ September 2021
}

* Asst. Prof. Šimun

Bilokapić, Ph.D.,

Catholic Faculty of

Theology, University of Split, Zrinskofrankopanska 19,

21000 Split, Croatia, simun.bilokapic@ st.t-com.hr

** Asst. Prof. Ana Jeličić, Ph.D.,

University Department of Forensic Sciences,

University of Split, Ruđera Boškovića 33, 21000 Split, Croatia, anjelici08@gmail.com

Summary: Having offered a short presentation of the phenomenon of pornography, in particular its common, yet ominous presence in the means of social communication, the paper focuses on the analysis of the relationship between pornography and sexual violence. By employing theories of family violence and especially, theories of sexual violence, the paper examines connection between pornography and sexual violence, analyses offsetting $\gg$ pro et contra $<$ views concerning this interrelation, and possible interests lying behind contrary arguments. The paper proceeds with a detailed analysis of the document issued by the Pontifical Council for Social Communications $\gg$ Pornography and Violence in the Communications Media «, followed by an anthropological and ethical analysis of the relationship between pornography and sexual violence. The deceit and deception of the dilemma lies in the fact, the paper concludes, that pornography and sexual violence are not only in a causal relationship, but these are two very similar phenomena, almost the same by (their) nature and content, the result of the same mentality and culture with the same devastating effects on a person and person's sexuality.

Keywords: pornography, (sexual) violence, addiction, Internet, anthropology, ethics.

\section{Introduction}

Over the last decades, pornography has changed according to qualitative and quantitative research perspective. It has become omnipresent and massive and has also entered all pores of the society, overwhelming all its sectors, not ex- 
cluding even the private one - the family sector - and thus became accessible to all, even the youngest ones. Wherever there is a screen, there is pornography as well. Roughly speaking, it has become an indispensable item in children's pockets and school bags. At first, interested and oriented only to the explicitness of the sexual act and relationship, but over time, and especially nowadays, this explicitness has grown into a more violent and dehumanizing form. Sometimes it is possible to find a voice that speaks about the harmful effects of pornography and its omnipresence. However, the general silence on the issue at a broader social level is startling. The silence was no stranger in the Church either. This is not something people educate on, it is neither being preached nor is it a part of upbringing. Much like other sexual sins, it is rarely being confessed. One could perhaps on rare occasions be addressed to the judgement of the Church clearly stated in the Catechism of the Catholic Church in the context of God's Sixth Commandment. ${ }^{1}$

There were times when the addressed issues were discussed at length, vigorously, and thoroughly. Not today. The human spirit has fallen silent and left to live in the moment outvoiced by aggressive supporters of pornography production and consumption. Among the questions to be addressed is the relationship between pornography and sexual violence. Apparently, society has become eroticized and sexualized. This is best exemplified through the relation to the body, especially the female body. The female body is owned by the marketing industry, often commercialized and genitalized, displayed in a way to arouse sexual desire and please common sexual fantasies or encourage them (Galimberti, I vizi capitali e nuovi vizi 93-98). By observing another person's body merely as an item, in film or photography, one gets numbed into sexual pleasure without the other, in radical loneliness and hidden narcissism, in one's self-abuse. Every form of (female) body commercialization creates perverse relationships, ones without reciprocity, love, or respect (Galimberti, Le cose dell'amore 55-56). It is due to habitual behavior, insensitivity of the matter, even indolence for the issues, that the bigger problem than the porn industry itself became the emergence and forced preservation of porn culture. Such a culture should raise new questions. One of them includes the connection between

\footnotetext{
${ }^{1}$ Accordingly, pornography consists in removing marital and any other form of the intimacy of the partners, as it is a form of exhibitionism, perversion of the conjugal act as well as a direct offense against chastity, grave injury to the dignity of all its participants, producers (actors, vendors) and consumers (the public), objectivizing each one in their unique way. It is a serious transgression. Theologically speaking, it is a sin. In terms of value and aesthetics, it trivializes and vulgarizes human sexuality and relationship. And, it is only a part of the reason why civil authorities should prevent the production and distribution of pornographic materials (Catechism of the Catholic Church no. 2354).
} 
pornography and sexual violence. ${ }^{2}$ Sexual violence in the pornographic industry has many forms. Two of the most frequent are physical and verbal. The first one refers to the use of physical force to obtain sex, and the second one refers to verbally coercive communication to obtain sex and sexual harassment. (Wright et al. 187) Pornographic videos most commonly contain scenes where women are (in $97 \%$ of the scenes) targets of physical aggression as: spanking, slapping, gagging, hair pulling and choking. Aggressive behavior in form of insult and name-calling are the most usual types of verbal aggression (Fritz et al. 3047; Bridges et al. 1075).

Sexual violence includes various physical forms of violence, but other forms of abuse too such as $\gg$ sextortion, sexual coercion, rape, explicit videos, text messages or emails sent to a victim and similar. Damage caused to victims may be physical, psychological and social « (Žilić and Janković 75).

Sexual abuse, however, refers to different ways of sexual exploitation and harassment like molestation, assault, embarrassment, unwanted touching, or unwanted recording or photographing (Žilić and Janković 79). Although abusers in intimate relationships can be both men as well as women, females were still most likely to be victims of sexual violence. Through each form of violence, including this, the perpetrator tries to maintain control over the victim by restricting the freedom of thought and the movement of the person he exerts violence on. However, it is interesting that when it comes to numerous risk factors for family violence and violence in the intimate partnership, regardless of the sexual orientation, pornography is practically nowhere mentioned, at least not in Croatian scientific journals, even though empirical research on the correlation between pornography and sex offenses (rape and lewd acts) and perception of sexuality in young people who consume pornography does exist. ${ }^{3}$

\footnotetext{
${ }^{2}$ According to the definition of World Health Organization (WHO), sexual violence is defined as any sexual act, attempt to obtain a sexual act, unwanted sexual comments or advances, directed against a person's sexuality using coercion, by any person, regardless of their relationship to the victim. Coercion may involve various degrees of force, including physical force, threats, or blackmail for endangering the welfare and/or life of the victim itself or someone close to the victim. More in the document of WHO: »Understanding and Addressing Violence against Women.« apps. who.int/iris/bitstream/handle/10665/77434/WHO_RHR_12.37_eng.pdf;jsessionid =63BF0C 72837E865D76816FF57674443C?sequence $=1$. Accessed 2 July 2020.

${ }^{3}$ See more in scientific papers: Landripet, Ivan. »Testing the Influence of Pornography on Sexual Violence in Croatia: The Public Crime Statistics Approach.« Društvena istraživanja, vol. 16, no. 1-2, 2007, pp. 269-93.; Štulhofer, Aleksandar, et al. »Rizici pornografije? Empirijsko testiranje uvriježenih predodžbi o konzumentima seksualno eksplicitnih sadržaja.« Revija za sociologiju, vol. 34, no. 1/2, 2003, pp. 75-96; Klasnić, Ksenija, and Aleksandar Štulhofer. »Prihvaćanje mitova o silovanju među adolescentima: longitudinalna medijska studija. ¿ Društvena istraživanja, vol. 27, no. 2, 2018, pp. 221-42. A prominent recent study appeared, conducted by Aleksandar Štulhofer, which
} 
A fundamental idea of this paper lies in the attempt to determine the nature of the relationship between pornography and sexual violence. The results of such analysis could encourage discussion on the negative effects of pornography with the respect to the values addressed in Catechism of the Catholic Church (the intimate partnership, the culture of concealment and demonstration, pleasure, the virtue of chastity, nature of the conjugal act, mutual self-giving, human person and human dignity) as well as on the need of civil authorities to clearly articulate their attitude toward this pervasive and often devastating social phenomenon.

To understand that, it is necessary to say more about the phenomenology of pornography.

\section{Definition, Types, and Nature of Pornography}

Being an omnipresent, everyday, commonly and widely used concept, even outside sexual context, pornography no longer requires us to seek special studies in sexology, various encyclopedias, and dictionaries of moral theology to offer a precise and exhausting determination of the concept. Public discourse suggests pornography as sexually explicit content produced for commercial purposes, and distributed through comic books, magazines, the internet, and videos. It was classified into softcore and hardcore pornography. The first type is also known as erotica and contains nudity in sexually suggestive situations without explicit sexual activity. ${ }^{4}$ The second type, hardcore pornography, features visually explicit, real, not simulated sexual activities. While erotic (audiovisual) contents suggest sexual activities,

lasted from 2015 to 2018 and encompassed 59 secondary schools from Zagreb and 14 secondary schools from Rijeka, in total 2200 high school students in Zagreb and more than 1300 in Rijeka, on the influence of pornography and other sexual media on youth, their sexual and reproductive health, psychological welfare and the image they have of themselves.

${ }^{4}$ In visual terms, erotica is more frequently displayed through photographs in magazines and web pages. However, certain visual images do not necessarily show either real people or nudity. Erotic content very often includes fetishes like special clothing, uniforms, footwear or sex toys, dolls, various items, and similar. A majority of authors who in any way deal with the issue of pornography, quite rightly, attempt to separate erotic from pornographic. Many argue that erotica is not and cannot be pornography. There is a difference between them. Different settings, intentions, context. Pornography, as Chimirri G. suggests, is an improper and surreal use of erotica. Eroticism is a constitutive and positive element of sexuality, while pornography is its enemy. Pornography is a commercial manifestation of the body's sacrality, nudity, sexual pleasure, beauty, and love. It cannot be reduced to the neutral public presentation of eros and the naked body since it is already by itself something obscene, shamelessly trivial, violent, ignorant, antisocial, and psychopathological. Pornography is about undermining the dignity of the other, it is a permanent offense to shame, a cynical parody of sex, its destruction, and trafficking, the excessive eroticization of everything, nudity in particular (Chimirri 75-76). 
where dialogues, at least to some extent, show mutual reciprocity and respect between partners, pornography quite often presents sexual activities in the context of domination, subordination, degradation, or belittlement of one of the sexual partners, most frequently women in a heterosexual relationship (Jensen 1-2). In the broad sense, pornography refers to every (audiovisual) material which causes sexual arousal or is attractive in a sexual way.

Images of sexual behavior can be autoerotic, like self-fornication, but it can display, which is more common, sexual relationship between two or more persons; this being either lesbian, homosexual, or heterosexual. Certain types of pornography really display sexual behavior, and not necessarily sexual relationship, since there is none. Therefore, it is impossible to talk about relationship in cases which involve zoophilia, necrophilia, different forms of fetishism and similar, i.e., where engaging into sexual activity with something that can neither be called human nor can such activity be even considered human since it misses reciprocal relationship, one of the main features of human sexual relationship. Law recognizes legal and illegal pornography. All types of pornographic content, apart from those which include minors, are legal, even those which display rape and other forms of brutal, sadistic, and masochistic relationship, physical abuse or punishment, as well as pornography which contains abuse, even killing of another living being (Johnson 239).

Numerous studies where controlled groups are used to examine the incidence of violence in pornography, have brought researchers to the conclusion that pornographic content can be classified into three categories: overtly violent pornography, nonviolent pornography but degrading, sometimes called dehumanizing pornography, and sexually explicit pornography that is neither violent nor degrading (Jensen 1).

The purpose of pornography, which at the same time, explains its popularity, lies in satisfying the sexual desire, urges, and all kinds of sexual phantasies of its consumers. According to some researches, it is like a playground reserved for fulfilling deviant and violent fantasies, simultaneously being a training ground for practicing future behaviors in the sense that what is fantasized and seen can easily be assimilated in the real world, life, and a relationship. It is a well-known fact that imagination has immense power and influence on the behavior manifested in real life. People who use pornographic content to indulge their sexual fantasies, actually encourage and advance themselves to imitate such behavior in real relationships with other people, as will be showcased in the presentation of social learning theory. However, it does not mean they will by and large fulfill their fantasies. In that sense, some therapists even recommend pornography to certain people to enhance their sex life. In addition, many experts in the field are more concerned about the negative 
than the $\gg$ positive « effects of pornography consumption. This refers to promoting and empowering selfishness, artificiality, (always present) addiction problem, control desire, and other even more dangerous consequences of any pornography consumption, violent and dehumanizing in particular (Jensen 1-2). ${ }^{5}$ The person who consumes pornography is usually alone and lonely in all that, with another person serving merely as an object of sexual satisfaction, some kind of depersonalized sexual service.

In this game there is no two-way communication, reciprocity, alterity, live interaction with another person, and neither is there any responsibility for the matter.

Consequently, it could be argued that P. Šolić is right when he says that:

$\gg$ Pornography leads a person into imaginary and fantastic spheres which are being experienced as real. Detached from reality, the person dehumanizes himself by observing enticing techniques thereby falling into insignificance. Sexuality is reduced to a pure technique where human sensitivity and warmth are completely denied. This degrades the human body and reduces it to a kind of machine which needs to act in a sexually satisfying way. In turn, it carries along emotional neglect and radical emotional impoverishment, which is normally based upon the responsibility and gift, or to be more precise, upon love $\ll$ (58).

His assertion is even more plausible if the attention moved to the pervasive nature of pornography on the internet, encouraged and created for commercial reasons.

\section{Pornography and Internet}

The means of social communication used in digital form by a majority of mankind have improved accessibility, consumption, reproduction, distribution, production, and spread of pornographic material that is almost impossible to control. By becoming free, the last barrier preventing pornographic content to be widely available literally to everyone has been broken down. In addition to digitalization, wide-

\footnotetext{
${ }^{5}$ Scientists who work in the field of criminology have through large-scale studies come to a clear conclusion that common consequences of continuous and frequent consumption of pornographic contents are mostly negative and destructive. Accordingly, they excluded the possibility for pornography to have positive effects on men. They also share the conclusion that sexual perpetrators and misdemeanants have different predispositions to violent behavior where pornography is only a trigger regardless of pornography. This is especially highlighted in debates and researches aimed at proving a hypothesis according to which, for instance, child pornography may perhaps help reduce if not eradicate rape, sexual exploitation, and abuse of children; or hypothesis which presupposes that watching pornography can divert someone from rape by simple satisfying their fantasies through watching pornography (Johnson 240).
} 
spread distribution of pornography is also possible thanks to the mobile modern communication and media devices and user anonymity. Moreover, pornographic content is no longer reserved just for huge industrial machinery, as it is not seldomly a »homemade product «, easily produced and simply distributed with the help of all sorts of communication tools, and increasingly through social media. In turn, excessive use of social media has led to the emergence of a new type of addiction. Understandably, internet pornography addiction has become a growing problem. Like any other addiction, this too paralyzes a person. »One can become physically and chemically addicted to it the same he can to alcohol, drugs, or gambling. Pornographic images are being cut into our imagination. The deeper the cuts and more frequent are, the harder the path to freedom is. (...) To achieve the desired effect, more and more images are needed « (Finn 21-22). Some argue that a pornography addict is merely an ordinary and, in many aspects, impotent consumer, but who can over time cause and yield many, above all, harmful consequences. ${ }^{6}$

Internet, for the most part, uses an image (videos or photographs) as a powerful communication tool. An image has a very stimulating power. It is an enticing media that allures the audience with ease and retains its attention. In other words, the image gets carved into memory. It does not disappear, instead, it ferments, grows in the eyes of its viewers often seeking its actual realization. Thanks to the internet, it is very simple to return to that image or replace it with another. Pornography uses the same media.

Pornographic content, regardless of the form it comes on the internet or any other mass media, is a constructed, directed, industrial product whereby human lust, drive, and weakness are used to create profit as its primary purpose. It is popular because to some degree it succeeds - to »satisfy « its consumer. Even more, people turn to pornography for many other reasons also. For instance, to eliminate or ease boredom or loneliness that, nota bene, very often or even regularly is precisely the effect of pornography consumption. A consumer is then found in a vicious circle, mainly burdened by a strong sense of guilt. Therefore, it should not come as a surprise that dissatisfaction, fear, sadness, and disappointment in real life come as common effects of exposure to pornography (Cucci 261-313). ${ }^{7}$

${ }^{6}$ More on the topic: Cucci, Giovanni. Il fascino del male. I vizi capitali. Edizioni AdP, 2008., pp. 261313.

${ }^{7}$ Such an example is the following phenomenon. Lost in the real world, in the inability to find partners they expect, thereby living celibacy they never wanted has brought to the development of the new sort of subculture. Incels ('involuntary celibates') are usually heterosexual men who blame women for their problem of loneliness. In 2017 incel community on the internet had 40000 members. They call women femoids to show their belief that women are nothing more than robots with female sexual features. They even require decriminalization of rape from the authorities and demand them to $\gg$ ensure $\ll$ women for all men. 


\subsection{Internet Pornography by the Numbers}

In addition to the troubling aspect of pornography quality, the amount of pornography consumption, equally worrying and self-explanatory by now, should also be addressed. Pornography production closely meets the requirements and vice versa. Pornographic internet sites are being visited by 2 billion people in the world. Only in the U.S.A. people spend around 20 billion dollars on porn videos, 7.5 billion dollars on porn magazines, around 2.5 billion dollars on cable TV with adult channels, while porn's annual revenue of American TV stations amounts to 6.2 billion dollars. Internet pornography brings a profit of 2.5 billion dollars, whereas world pornography revenue is 57 billion dollars (Finn 18-23). ${ }^{8}$

According to the results of a large 2004 study, $70 \%$ of men aged $18-24$ visited porn sites at least once per month, and $66 \%$ of those who visited sites are aged under 40. The same year recorded 372 million visits to porn sites, with 100000 websites containing illegal child pornography while precisely pornography accounted for $25 \%$ of all terms occurring in search engines. ${ }^{9}$

A more recent study conducted in Italy in 2016 included 600 children aged 12 18 and 600 parents aged $25-64$. The results showed that $73 \%$ of children (four out of five children) regularly watched pornography, more than half of them were male children and $28 \%$ of those children over the years became addicted to pornography. The same study also showed that one in ten children participated in the so-called sexting, i.e. using social media to share sexually explicit content through videos and photographs they create. Apart from severe and long-term psychological, emotional, even spiritual consequences, such behavior often results in distorted expectations for the actual people, especially the opposite sex. It also affects the understanding of sexuality and sexual relationships, resulting in a lack of 'real-life' experiences and leading to complete emotional estrangement. ${ }^{10}$

The consequences of pornography consumption are different. Back in 2004, data from one survey analysis showed that $30 \%$ of people feel like sexual objects with their spouse who frequently uses pornography, while $47 \%$ reported that pornography presents a great issue not only in intimate relationships but also in their home.

\footnotetext{
${ }^{8}$ See also: Mehta, Michael D. »Sex Online: Regulation and Pornography Surveillance in the Wired World.« Digital democracy. Policy and Politics in the Wired World, edited by Cynthia J. Alexsander, and Leslie A. Pal, Panliber, 2001, pp. 177-190.

${ }^{9}$ This data was obtained from the National Coalition for the Protection of Children and Families (Finn 20).

${ }^{10}$ Doxakids and Telefono Azzurro, $\gg I l$ tempo del web. Adolescenti e genitori online.« February 2016, www.doitbetter.azzurro.it/wp-content/uploads/2016/02/Telefono-Azzurro-SID-2016_rev_pFS_ DEF_3.pdf. Accessed 20 June 2020.
} 
In practice, this includes the inability to reach sexual satisfaction with a spouse, diminishing the value of fidelity to one person, or a belief that women enjoy roughness. ${ }^{11}$

The situation becomes significantly worse if pornography includes violence, as one American 2019 study suggested, stating indirectly a close connection between pornography and rape. According to data from this research, $64 \%$ of the student population (to 24 years of age) watched pornography on the internet at least once a week. The most visited porn site was Pornhub with $15 \%$ of videos showing violence, i.e., connecting sexual pleasure to violence, while rape was portrayed as a relationship which $95 \%$ of women enjoy. Analysis of the 50 most popular pornographic videos on Pornhub found that $88 \%$ of scenes contained physical violence and that $49 \%$ contained verbal aggression.

What comes as alarming is the fact that such places and representations harbor and propagate dangerous myths and stereotypes where victims of violence derive pleasure from aggression. Experts argue this encourages violence for several reasons: the raped woman enjoys the act; a woman gets what she deserves; a rapist hence, does not need to be punished; women falsely accuse men of rape and similar. These are the reasons behind the growing number of people entering abusive sexual relationships. Women engaged in this type of pornography commence to tolerate violence in the real-life, and men begin to fulfill their violent sexual fantasies as it is being approved and considered common and normal sexual behavior. This study compared 22 scientific pieces of research and proved the initial hypothesis that pornographic content containing violence is related to the growing number of physical and verbal violence in everyday life. ${ }^{12}$

A study published in 2020 shows that $45 \%$ of Pornhub scenes had at least one act of physical aggression, while $35 \%$ of scenes from Xvideos contained violence. The sample size for Xvideos is 3435 scenes, and for Pornhub, the sample size is 547 scenes. Women in scenes of violence either pretended pleasure or they tolerated and accepted it. In $76 \%$ of scenes, men were the aggressors against women (Fritz et al. 3047).

If a qualitative analysis of pornography asserts, among other things, the possibility of people falling victim to sexual violence, then quantitative analysis indicates the

${ }^{11}$ This refers to the study by Yarhouse, Mark A. Marriage Related Research (Finn 20).

${ }^{12}$ The authors refer to the research aimed at studying the causal relationship between pornography and sexual violence, abuse, and harassment on American colleges: The Influence of Pornography on College Sexual Assault. Research results available: www.endsexualexploitation.org/articles/institutions-of-higher-violence-the-influence-of-pornography-on-college-sexual-assault/. 20 March 2019. Accessed 2 July 2020. 
prevalence of violence, hence the pain and suffering of real, everyday people caused by the use of pornography.

Although qualitative and quantitative analyses of pornography address a serious social problem and the need, as CBC states, for the civil authorities to intervene, still, this does not happen. The reasons for this can be very prosaic, far from those ethical and purely human reasons.

\subsection{Supply and Demand in Media}

As it has already been pointed out, pornographic content (violent or nonviolent) is mostly the fruit of a very powerful (predominantly) film industry that exploits and manipulates human sexuality for profit. The onset of pornography as an industrial product happened after the Second World War. Until then it was regarded as a type of organized crime. Nowadays the porn industry makes an unimaginable amount of money. It is believed that in 2002 with the release of more than 11000 new hardcore videos, pornography earned over 10 billion dollars. Over time, society has acknowledged pornography not only through legislation but through culture as well. Modern society is no longer only eroticized or sexualized, as it was regarded during the 80 -s of the $20^{\text {th }}$ century, instead, it has become increasingly imbued with pornography. What is the most disturbing when it comes to the pornographization of society, is the gradual intensification of any form of brutality towards women and children, the most frequent victims of sexual violence. As R. Jensen observed, there is virtually no relationship of power and impotence, domination and subordination that is not pornographized (3). By analyzing what people seek the most from pornography, the author confronts directors who find themselves in front of growing demands for extreme forms of sexual violence in (porn) videos, sadism, and brutality in hardcore materials.

The question of the state not engaging in the $\gg$ pornography matter $\ll$ is quite simple, contemporary, pragmatic, market-related. This is solely about the relationship between supply and demand with no excessive $\gg$ naggings $\ll$ involved whatsoever, including ethical considerations.

The conveyed views aimed to show the killing potential of (sexual) violence that exists in $\gg$ harmless $<$ pornography and that is often fitted into the area of human rights and freedoms, in case a relationship between pornography and sexual violence proves to be a disgrace to the contemporary society which, like pornography, changes for the worse in terms of quality and quantity. 


\section{Is there a Connection between Pornography and Sexual Violence?}

Numerous theories of family violence (see for example: Hines and Malley-Morrison; Barnett et al.; Kurst-Swanger and Petcosky; McCue) and in particular most theories related to the etiology of sexual violence (Ellis), suggest that pornography plays a very significant role when it comes to family, especially sexual abuse. This is supported by many lab studies and field researches. The findings encompass various forms of marital violence and rape, one of them being the so-called obsessive rape. What stands as a common feature of all (sexually) abusive partners prone to such behavior is their propensity to perversion and the bizarre. They are obsessed with sex and pornography and use it regularly, but they are also the generators of pornography where their spouses play a crucial role. However, their obsession and ruthlessness make them go to such lengths as to even exploiting their own children. They often resort to coercive and violent methods to execute their perverse inclinations and desires. When it comes to family violence, their actors are not so much aroused by the victim's pain or suffering as they are by the perversity of the very act, often inspired precisely by pornography to which they force their spouse and children (Finkelhor and Yllo 157-160, Allison and Wrightsman 94-95). Also, a very precise and detailed typology of incestuous families includes a type of family featured by perverse or pornographic incest. It refers to a bizarre and obscene incestuous relationship that is generally documented in audio-visual format to be distributed to the people of similar predilections and interests or to simply serve as an impetus to its manufacturers (Joraschy 84).

Most theories on family and sexual violence emphasize a strong relationship between pornography and violence and there is a lot of evidence going in their favor. A small part of these theories and their advocates, however, believe that these two, pornography and violent sexual behavior, cannot be directly related in the sense that, for instance, nonviolent pornography could cause, instigate or trigger sexual violence against women and children. Both standpoints are supported by relevant lab studies and field researches. ${ }^{13}$

Therefore, this would imply $\gg$ two truths « related to a really strange relationship between the two phenomena. The analysis of different standpoints ( $\gg$ two truths $\ll$ ) revealed doubt that the attitude towards pornography was created or inspired by a genuine desire to discover the real truth behind the relationship between pornog-

${ }^{13}$ Dilemmas at the beginning of the discussion on the impact of pornography on violence are continued today as modern literature illustrates, and it seems it will become one of the recurring debates in the future as well. (See more in: Fritz et al. 3041-3053; Wright et al. 183-205; Ferguson and Hartley 323-329; Malamuth et al. 26-91). 
raphy and violence. Instead, it came as a separate set of values or as an ideological and political attitude pro et contra and as such is censored.

In other words, a discussion that results in $\gg$ two truths $\ll$ is often reduced to a very simple formula, two fundamental attitudes: if pornography causes sexual violence, it should be censored, and if it does not affect sexual behavior or it is not supported by plausible evidence, then it should not be censored in any way. However, there is the third attitude which is especially surprising and wondering. This attitude correlates with feminist theories according to which pornography, even if it had little connection to sexual violence, should not be censored due to certain basic human rights and »positive impacts « on the life of women and men, as presented earlier through the discourse of certain therapists. According to another similar argument, pornography is a tool for relieving aggression, some sort of alternative which helps prevent or at least reduce various forms of sexual violence and rape (Strossen; Landripet 269-293). Hence, no matter how good this topic is or how desirable would be to find solutions to the dilemma on the influence of violence on pornography, one still needs to be careful since both can be deceptive or used for manipulating the actual relationship and interdependence between pornography and violence. Respectively, it would be dangerous to neglect by far the most important thing, and that is the starting point of the proposed dilemmas which, as this paper will show, deeply delegitimizes both, regardless of their correlation.

The question of pornography and violence is also raised by Pontifical Council for Social Communications in the document $\gg$ Pornografia e violenza nei mezzi di comunicazione: una risposta pastorale « (Pornography and Violence in the Communications Media: a Pastoral Response). ${ }^{14}$ The document argues, although with a bit of restraint, that there could be a connection between pornography and sadistic violence in particular. Specifically, it refers to the type of explicitly violent pornography, both in terms of content and the way it is displayed. Moreover, the document contends that most consumers of pornographic materials risk translating such behavior and attitudes into their behavior and attitude, thereby risking losing any respect for others. This, supposedly, happens through the model of imitation or shaping. Unfortunately, these others are not just »others «, at the same time they are the children of God, brothers, and sisters of one human family. From the notion of God's children and mutual spirit of brotherhood and sisterhood comes all the drama which arises not only from sexual violence but pornography too ( $\mathrm{PeV}$ no. 12 and 13). Both fatal to man.

${ }^{14}$ Cf. Pontificio Consiglio delle Comunicazioni sociali, Pornografia e violenza nei mezzi di comunicazione: Una Risposta Pastorale, available at: www.vatican.va/roman_curia/pontifical_councils / pccs/documents/rc_pc_pccs_doc_04101989_criteria_it.html (hereinafter: PeV). Accessed 24 March 2020. 


\section{Theories on Sexual Violence in Pornography}

Two theories are dealing directly with the relationship between pornography and sexual violence: feminist theory and social learning theory (Ellis 9-54). Even though there is no clear reference to these theories in the aforementioned Church document, it appears they have been employed in the analysis and the conception of the phenomenon. Although these theories do not entirely coincide, a number of their representatives claim that pornography use influences violent sexual behavior. Accordingly, these theories distinguish between nonviolent, violent, and degrading pornography. ${ }^{15}$ It is precisely the feminist context and feminist discussions that over the past decades have offered perhaps the best analyses and answers to the phenomenon of pornography, including observations on its impact on both social behavior and sexual violence against women and children. All with the intention (not) to censor sexually explicit content, i.e. pornography (Siann 166-69).

\subsection{FeMinist THEORY}

Interestingly, though, feminist theory recognizes two completely different directions with regards to the real effects of pornography and the need for (non)use of censorship. Feminist arguments $\gg$ against censorship « can be summed up as follows: pornography does neither affect an individual's social behavior nor does it have any particular impact on the behavior against women and children. The latter implies that censorship would not in any way decrease sexual violence against women and children. The point is, they argue, that violence against women and children has existed long before pornography. Therefore, it would be historically implausible to argue there was any specific reason that would explain the connection between today's violence and, availability and consumption of pornography. Also, the fact that pornography is widely used among violent individuals does not prove anything because these abusers would be aggressive regardless of pornography. Accordingly, they conclude that pornography does not produce sexist attitudes or violence in society, but rather reflects it. The proliferation of pornography happened quite recently while the oppression and subjugation of women and children date from the beginning of time (Siann 167). That being so, the supporters of anti-censorship argue that pornography should not be considered responsible for women's subordination. Moreover, they believe that censoring anything, including pornography, compromises fundamental human rights, foremost, the right to liberty and freedom of expression. Censorship is generally viewed as an attack

${ }^{15}$ Supporters of social learning theory especially and only a few advocates of the feminist theory insist on differentiating between nonviolent, violent, and degrading pornography, as was discussed earlier in the paper (Ellis 34-36). 
against freedom of civil liberties for the entire population in an attempt to diminish them. They even tend to assert that pornography censorship would bring more harm than good to women's rights and their security (Strossen 8$).{ }^{16}$ What comes as surprising is their vigorous attempt to defend pornography under the notion of tolerance. They justify the myth against which feminists struggle for decades, being it a very dangerous ground for the realization of the worst types of rape. Namely, according to this myth, women enjoy being raped. Rape fantasies that appear in pornographic videos, this standpoint suggests, can sexually arouse some women, and that is considered positive. It turns out that what is a nightmare to some women in the real-life, can become $\gg$ a dream come true « in another woman's fantasy. It is called a woman's secret erotic need (35). ${ }^{17}$

Feminists who advocate complete pornography censorship are determined to judge and formulate fundamental hypotheses offered by anti-censorship supporters. According to them, pornography is a theory, and rape is practice. ${ }^{18}$ The connection between the two is direct, immediate, and very tight. Pornography is the expression of male domination, power, and control; it is the icon of male supremacy, effective means of female subordination, and intimidation. It »usurps « the female gender, a woman's body is being possessed, and woman is taken, used, scorned, and rejected. Sex becomes a foundation and a powerful tool for discrimination, especially against women and children (Siann 169). ${ }^{19}$ Moreover, the attitudes and hypotheses

\footnotetext{
${ }^{16}$ Any arrangement, as supporters of this theory believe, which would attempt to censor pornography would signify the violation of rights, making harm to women's interests in many ways. It would suffocate many good deeds which are valued by women and feminists; it would give rise to discrimination against weaker groups, including feminists and lesbians; it would perpetuate demeaning stereotypes towards women including a stereotype where sex is harmful and inflicts evil upon them; it would be very demeaning to perceive women merely as victims; this would question the responsibility in cases of discrimination and sexual violence against women; it would significantly affect women who voluntarily work in the sex industry; it would empower right-wing politicians whose patriarchal mindset would also diminish women's rights (Strossen 117). About other positive effects of pornography from this standpoint: Strossen 58.

${ }^{17}$ It may be that some women can discern between reality and fantasy, as this feminist theory suggests. However, it is highly questionable how many men can do the same. Social learning theory, as we will see, insists on the mechanism and the need for imitating everything one sees in social communication means, in images that shape and model everyone, and particularly those mentally unstable.

${ }^{18}$ This powerful anti-pornography slogan is attributed to Robin Morgan Segal (Siann 168).

${ }^{19}$ The entire terminology used to describe the pornography phenomenon can equally be applied, even without adjustments, to the definition of sexual violence phenomenon suggesting that: if rape is socially discarded and proscribed behavior, then the pornography phenomenon deserves the same treatment.
} 
they elaborated on do not provide a significant distinction between nonviolent, violent, and degrading pornography.

Catharine A. MacKinnon holds that pornography, other than its close and indisputable connection to rape, is in many ways harmful to women. That pornography can be harmful is already visible from the examples of women involved in pornography production (actors), those who directly participate in its making. They can be beaten, tied, humiliated, and sometimes even murdered. Real, and not faked or fantasized! Another devastating effect of pornography MacKinnon derives from the fact that pornography sexualizes asymmetry between man and woman. Inequality, i.e., male domination and women's subordination become $\gg$ somewhat sexy«, they become sexually appealing reality (MacKinnon 101). N. Strossen explains the basic idea behind this feminist theory asserts that pornography institutionalizes male sexual supremacy (5).

For feminists who support censorship, examples from everyday life undoubtedly confirm that exposure to pornography significantly increases discrimination and aggressive behavior against women and children. Working in safe houses, with prostitutes, incest victims or rape victims and lab studies, all reinforce their fundamental hypothesis (MacKinnon 102). Future harmful effects of exposure to pornography, according to C. A. MacKinnon, refer to trivialization and objectivization of women as well as to rape myth acceptance and similar (103). Rape is influenced by pornography by depriving men of inner inhibitions innate to certain men in a way that objectifies women. It is the same as what a rapist does while sexually assaulting women in the act of rape. Precisely this notion encourages feminists to advocate the censorship theory since any differentiation between nonviolent and violent pornography is entirely useless being it only a way, i.e., an attempt to legalize the so-called nonviolent pornography. Pornography of any type is simply regarded as the fuel of somebody's sick fantasies which does not exclude the shameful act of rape (Allison and Wrightsman 42-43).

Conclusively, they justify pornography censorship by claiming that as long as there is pornography, there are women and children who will be used and abused in the making of it, while such actual (ab)use will lead, as an inspiration, to further abuse of women and children since that is one of the most direct and the most evident harmful effects of pornography (MacKinnon 105).

Pornography, therefore, is not merely an expression of human freedom as anti-censorship advocates argue, instead, they are against it, since it is a means of women's abuse and subordination. Hence, a woman is free of violence only when pornography is removed rather than promoted. Since it is raised on inequality and the model 
of dominance and subordination, pornography violates fundamental human rights and as such should be considered illegal (Siann 169). ${ }^{20}$

\subsection{Social Learning Theory}

According to the second theory, social learning theory, pornography is a direct cause of sexual violence (Ellis 12-14, 33-41). A strong impetus to this theory was offered by the $\gg$ Presidential Commission on Pornography and Obscenity « by stating in 1973 that exposure to pornography would not significantly increase aggression or other forms of asocial behavior. The Commission faced heavy disputes coming from the advocates of the second theory but also from some representatives of the feminist theory (Eysenck and Nias 78-124). Those who oppose the Commission's conclusion and consider it completely unbecoming, base their claims on pornography researches that, some argue, did not exist before the 70 -s of the $20^{\text {th }}$ century, meaning that the Commission could not even have them as supporting evidence. This refers to violent pornography, in many cases imbued with explicit rape scenes in addition to the mixture of sex and violence, horror, and mutilation (Ellis 12). One social learning theory hypothesis asserts that exposure to violent pornography would increase men's inclination to commit rape or other types of violent behavior against women. However, what about the so-called nonviolent and degrading pornography? Considering the issue of correlation between pornography and sexual violence, and in particular, the nature of pornographic materials that would affect violent sexual behavior, social learning theory representatives have split opinions more than the feminist theory advocates do. Some researchers, along with feminists who support censorship, argue that any form of pornography, including nonviolent, is closely related to rape in one way or another and may therefore be regarded as its cause. One part of the social learning theory claimed that only violent pornography forms, especially those in which women supposedly enjoy, have some kind of possibility to increase man's tendency to commit rape. However, other representatives, assert that any form of degrading pornography can increase such tendency $(36){ }^{21}$

\footnotetext{
${ }^{20}$ If certain interests behind discussion on pornography censorship are set aside, the weirdest fact remains that, as shown, both feminist currents are radically diverse, and their basic notions and hypotheses are largely supported by field researches and lab studies, which is information that says more about the nature of such research than its content.

${ }^{21}$ Among researches dealing with the interrelation between pornography and rape, the one made by Zillman and Braynt draws special attention. Namely, it concerns nonviolent pornography which either degrades women or presents them as subordinate beings to men. They have exposed male volunteers to nonviolent pornography for six weeks. Based on the comparison between attitudes these men had for pornography before the experiment and later, it was concluded that these men have become: more tolerant to increasingly bizarre and violent forms of pornography; 2 . less interested in advocating gender equality; 3 . more tolerant and compassionate when it comes to punishing sexual violence perpetrators (Ellis 39-40).
} 
Some researches have attempted to determine the real nature of violent pornography that would promote rape. Accordingly, violent pornography consists of two elements: the explicit and violent aspects of the sexual act and sexuality in general. Linz, Donnerstein, and Penrod insisted that when it comes to promoting man's tendency for rape, the explicit aspect was not important as the degree of interplay between sex, aggression, and violence, which goes in favor of those who are against censoring nonviolent pornography.

It is also important to notice that many research results indicate that men's exposure to violent pornography forms increases their tendency to promote rape myths in which women want and deserve to be raped. The same effects are attributed to pornography videos that nevertheless, contain combined elements of violence and sex (Ellis 36). ${ }^{22}$

\section{The Attitude of the Church towards the Relationship between Pornography and Violence}

As aforementioned, the Pontifical Council for Social Communications also attempts to tackle the question about the connection between pornography and violence. $^{23}$

Having defined the scope of influence and the effects of pornography and violence on individuals and the society and upon qualifying them both as a sin while expressing contempt for the two phenomena (PeV no. 1-11) from a theological and moral perspective, the document continues to discuss the sensitive relationship between pornography and (sexual) violence and their possible interrelation. Referring to the results of social learning theory, the document asserts that sadistic violence can significantly affect people who are easily impressed, and this mostly includes younger people and adolescents, to such extent that violence is promoted as something acceptable, normal, and worth imitating (PeV no. 12). When it comes to defining the relationship between pornography and sadistic violence, the document does not offer anything new, rather, it leans on researches and opinions of other experts who suggest that pornography, violent in its expression and content, could influence views and behavior of its consumers and bring them to the point of losing any respect for other people, addressing particularly to mentally unstable persons who are easily manipulated (PeV no. 13).

${ }^{22}$ Such studies consequently warn about the long-term effects of pornography exposure and also highlight the difference between lab studies and real-life examples as well as other effects of pornography like promiscuity or underestimating stable monogamous relationship or a spouse and similar.

${ }^{23}$ See footnote no. 14 . 
A downside of this document is that more attention is paid to the explicitness of the pornographic act rather than to the violence itself, as is evidenced through the distinction between $\gg$ softcore $\ll$ and $\gg$ hardcore « pornography. In addition to violent and nonviolent pornography analyzed by previously mentioned two theories, hardcore pornography could also include the third type, i.e. degrading pornography, to which the document never refers directly (PeV no. 14). Contrary to the clarity of the theories dealing with sexual violence, their advocates argued that there is no consensus on the matter, but a sort of reluctance or even uncertainty in the document as to what $\gg$ softcore « pornography denotes. Specifically, it is not entirely clear whether or not it affects sexual violence like the other two types of pornography. At first, it seems that softcore pornography is primarily interested in the explicitness of the act. Other theories might call it nonviolent pornography-far away from the concept of sexual violence. If we interpret the document well, it means that this type of pornography could only in time achieve that effect, i.e. that type of pornography could have desensitizing effects, suffocating gradually individual's moral sense to such extent as to make him morally and personally insensitive to rights and dignity of other persons. Only then, over time, postponed and indirect, could softcore pornography have violent effects. This supposition is supported by the next paragraph on the same issue in which the document took into consideration the so-called drug effect or progressive addiction which pushes an individual to more and more exciting and perverse products, here referred to as >hardcore $\ll$ pornography.

Over time, i.e. as the addiction progresses, the possibility to develop antisocial behavior leads to harmful effects as listed in the document in issue no. 15 and 16 $(\mathrm{PeV}){ }^{24}$

Apart from unhealthy behavior and effects, the document states that the worst thing of all would be if pornography would gradually become a stimulating and empowering agent, a type of indirect ally and participant, like in cases of severe and harmful sexual violence, kidnap and murders (PeV no. 17). Hence, the connection really exists.

\footnotetext{
${ }^{24}$ In issue no. 15 . and 16 the document lists the most frequent consequences of pornography use as follows: it stimulates fantasies and unhealthy behavior, compromises a person's moral development, healthy and mature relationships, especially in marriage and family life where they play a great role in addition to mutual trust, loyalty and moral integrity of one's thoughts and actions. Also, according to the issue no. 16 of the document, pornography prevents developing human character that is authentic to human sexuality inserting that if sexuality is a frenetic quest for one's satisfaction rather than an expression of continual love in marriage, then pornography could disturb the entire concept of family life (PeV, no. 15 and 16).
} 
Other than claiming that there is a connection between pornography and violence, perhaps the most important assertion in the document is that pornography and violence attempt to deny the image of God which is reflected in every person, thereby weakening the institution of marriage and family life, and causing severe harm to individuals and society. This assertion could help us avoid the trap in which may easily fall those who analyze the relationship between pornography and sexual violence and consequently, advocate or are against censorship. Their dilemma, if it were not tendentious, is actually reduced, simplified, shallow, yet very deceitful: if the effects of pornography on violence cannot be supported by evidence, some argue, pornography should not be censored due to many reasons, including seemingly beneficial effects pornography has on groups of people and individuals; but if pornography use could be associated with sexual violence, others argue, it should be censored precisely for that reason. Although we can agree on the latter, it may still be deceiving because it threatens to $\gg l u l l \ll$ those who act to fight violence against women and children by deluding them into a false belief that by censoring pornography one also censors violence. However, sexual violence is far older than pornography. Hence, the dilemma can neglect the fact suggested by the document according to which pornography and violence come from the same place, they are products of the same mentality, mindset, culture, milieu, which degrade sexuality, pervert human relationships, captor and overpower individuals, destroy marriage and family, inspire anti-social behavior, weaken society's moral strength (PeV no. 10). Therefore, it is important to observe that the document begins with a statement about radical changes concerning the way values are perceived and lived which then reflects the way people think and act.

\section{Exploring the Relationship between Pornography and Sexual Violence through Anthropological and Ethical Considerations}

More than an ethical issue, pornography and violence are foremost anthropological issues, an open anthropological challenge. Both denote a reductive conception of men, depersonalize and dehumanize them. It needs to be stressed that any act of humiliation is also a prominent ethical issue.

As emphasized several times, the effects of the relationship between pornography and sexual violence demonstrate that both phenomena separate sexuality from a person by reducing her to an object that is easy to manipulate for bare sexual pleasure or sadistic satisfaction which derives from suffering, pain, and abuse. Hence, it can be manipulated, distorted, and subjected to the logic of violence as well as to the logic of the market (Aliotta 134). 
Another consequence of sexual depersonalization which takes place in pornography as well as in sexual violence is reducing man to his biological component, i.e. to the genuine feature of a biological individual which can, again, be called objectivization or realization of human sexuality. Depersonalization or deprivation of the personal, whether in a pornographic or sexually violent encounter with another person, is being installed rendering the relationship between domination and possession possible. Erotica therefore degrades, deforms, and eventually turns into pornography, while human sexual encounter which should be imbued with mutual devotion, bestowal, and love turns into a repudiation of all that and transforms into egoism, selfishness, and hate, unilateral act of violence against another person. Similar to pornography, violence also implies deprivation of its vital and original component - the relational aspect. It is only upon distancing from oneself and through interaction with other people that a person can grow and enrich himself; he needs to distance from his $\gg$ greenness $\ll$, misery, and poverty if he gives himself to another. Bare pleasure, desire for possession stemming from these two phenomena, directly oppose to the giving and awareness of it. If that is so, then pornography and violence present men's utter impoverishment since it misses the genuine and authentic relationship. These people have another person, a body and human sexuality living inside them, guided by the distorted logic of management and possession instead of the logic of serving and giving. These are the two forms which apart from being extremely dangerous, are egoistic, closed, narcissistic; there is neither the presence of the other nor it needs to be in the way it is required in any other encounter. Both concepts are reigned by self-sufficiency, loneliness, and poverty. A man is like a prey in his own humanness and reduced to the pure physical (Muraro 877-80).

Pornography is, as M. Aliotta would argue, a symptom of collective anguish and pain which can only result in abuse and violence, it seems. Being unreal, fantasized, Aliotta explains, detached from the real, it can only trigger aggression and violence, hopeless gender alienation, all that just to find something that can never be found that way and it never will. Such people always remain little and are capable of causing great harm to themselves and to other people they meet (135). ${ }^{25}$

\footnotetext{
${ }^{25}$ All those who for various reasons scorn pornography with contempt mostly agree on its main consequences and effects, some of which are precisely given in the document of Pontifical Council for Social Communications: giving rise to masculine myths on masculinity and seduction; reducing sexuality to genitality; the cumulative effect of desensitization to immorality and violence (Stella 213-226). A careful analysis of pornography effects at the same time makes it easy to determine the causes of sexual violence, the cause-effect relationship between the two. The consequences of pornography consumption G. Kuby sums up in a way that it is possible, again, to recognize a close relationship between the two phenomena. She agrees with K. Meves who asserts that addiction to pornography often leads to sexual offenses, and the constant urge for strong stimuli leads to
} 
These arguments are largely supported by the analysis made on the influence and effects of pornography consumption on human sexuality and the relationship between men and women, given that is the most common area where sexual violence occurs. The body is devalued. It is no longer one's reality, but an instrument of pleasure in pornography, while rape is the space and area where one's frustrations and disturbed wishes come to life. The body is no longer personal, i.e., it is not the body that belongs to a person, and cannot be a word of the spirit, an expression of the soul. Instead, pornography and violence coerce the body to reside in the realm of its physical form, it is being silenced, unable to articulate other possibilities and expressions which are bestowed on him by his nature. This body is being deprived of the possibility to find himself, to become a home to authentic human encounter (Muraro 879-80).

Pornography like violence emphasizes the subordinate, servile, irrelevant role of woman in the man-woman relationship. A woman (child, an adult) is regarded as an item that should be used or disposed of as one wishes, even if this would include perverse and violent behavior. Pornography and sexual violence, feminists argue, go in favor of an androcentric vision of the world, determine the model of domination and subordination, but simultaneously revive these models and strengthen them thereby closing the circle of injustice, inequality, and violence. Not only against women but the elderly and children as well (Aliotta 136). ${ }^{26}$

Both phenomena are featured by a complete lack of interest, intentional or not, for moral values and by an utter misunderstanding of corporeality, but mostly by disrespect for the dignity of a human person. Pornography and violence, as Giovanni Chimirri notices, are two alibis of one period deprived of love, the period that uses sexual arousal as a way to compensate for the everlasting incurable dryness, loneliness, lack of joy, seriousness, heart spontaneity and similar shortcomings which on the level of values are pursued by a modern man with overrated values (Chimirri $75)$.

torment and rape, seldom to child abuse as a substitute means to achieve pleasure. Men, i.e. pornography users become cold to women, they lose respect for women and have more tendency to resort to violence. Pornography generously feeds upon the rape myth according to which women enjoy being raped. Comparison between users and non-users of pornography indicates that regular consumption of pornography triples the propensity for rape. Domination over another becomes a sort of reward for oneself (Kuby 215-220).

${ }^{26} \mathrm{Ola} \mathrm{W}$. Barnett and others refer to a new type of pornography that emerged on porn websites that reveal and show elderly people in sexually degrading positions. The authors compare this type of pornography to child pornography suggesting it as clearly illegal, in addition to its violent nature that does not necessarily imply the physical (586). 


\section{Conclusion}

In conclusion, it is possible to agree with the representatives of the feminist current who view pornography and sexual violence more as abusive, rather than sexual acts, more in the context of the Fifth Commandment than the Sixth Commandment. Sex is in both cases (mis)used as a tool for achieving other goals. Common consequences of both could be deformation of human sexuality in addition to objectivization, materialization, realization, insulting, and reduction of the other. This is why the conclusion offered by the Pontifical Council for Social Communications in the document on pornography is plausible when asserting that the restrictive and censorship attitude of the Church towards media is neither enough nor appropriate (PeV no. 30). True, it requires a lot more. A genuine anthropological revolution, authentic sexual anthropology that would never reduce a person, the body and spirit, sexuality to the means, but it would treat it as a goal, sexual anthropology that would denounce both sexual violence and pornography, as well as all other sexually offensive acts as morally and socially unacceptable. The pornography »culture « and rape mentality, which is undoubtedly a part of modern society, could only be tackled through $\gg$ metanoia $\ll$, a complete change of mind and heart of both, the society as a whole and a person.

\section{Works Cited}

Aliotta, Maurizio. Dona. Uomo. Per un'etica della sessualità. Edizioni San Paolo. Cinisello Balsamo, 1994.

Allison, Julie A., and Lawrence S. Wrightsman. Rape. The Misunderstood Crime. Sage. Newbury Park, 1993.

Barnett, Ola W., et al. Family Violence Across the Lifespan. An Introduction, Sage Publications, Inc. California, 2011.

Bridges, Ana J., et al. »Aggression and Sexual Behavior in Best-Selling Pornography Videos: A Content Analysis Update.«Violence Against Women, no. 16, 2010, pp. 1065-1085.

Chimirri, Giovanni. Psicologia della nudità: l'etica del pudore fra esibizionismi e intimità, Bonomi Editore, 2006.

Croatian Bishops' Conference. Catechism of the Catholic Church. Glas Koncila. 1994.

Cucci, Giovanni. Il fascino del male. I vizi capitali. Edizioni AdP, 2008.

Doxakids and Telefono Azzurro. »Il tempo del web. Adolescenti e genitori online.« February 2016, www.doitbetter.azzurro.it/wp-content/uploads/2016/02/Telefono-Azzurro-SID-2016_rev_pFS_DEF_3.pdf. Accessed 20 June 2020.

Ellis, Lee. Theories of Rape. Inquiries into the Causes of Sexual Aggression. Hemisphere Publishing Corporation, 1989.

Eysenck, Hans J., and David K. Nias. Sesso, violenza e media. Armando editore, 1985. 
Ferguson, Christopher J., and Hartley, Richard D. » The pleasure is momentary...the expense damnable? The influence of pornography on rape and sexual assault.« Aggression and Violent Behavior, no. 14, 2009, pp. 323-329.

Finkelhor, David, and Kersti Yllo. »Types of Marital Rape.« Rape and Society, edited by Patricia Searles, Ronald J. Berger, Boulder, Westview, 1995, pp. 157-160.

Finn, Robert W. Blessed are the Pure in Heart. The Dangers of Pornography. Glas Koncila, 2010.

Focus for Health. »How Pornography Impacts Violence. Against women and Child Abuse.« www.focusforhealth.org/how-pornography-impacts-violence-against-women-andchild-sex-abuse/. Accessed 27 June 2020.

Fritz, Niki, et al. »A Descriptive Analysis of the Types, Atrgets, and Relative Frequency of Agression in Mainstream Pornnography.« Archives of Sexual Behavior, no. 49, 2020, pp. 3041-3053.

Galimberti, Umberto. Le cose dell'amore. Feltrinelli, 2005.

---. I vizi capitali e i nuovi vizi. Feltrinelli, 2003.

Hines, Denise A., and Kathleen Malley-Morrison. Family Violence in the United States. Defining, Understanding, and Combating Abuse. Sage Publications, Inc. California, 2005.

Jensen, Robert. »Pornography and Sexual Violence.«VAWnet: National Online Resource Center on Violence Against Women, 2004, pp. 1-8, https://vawnet.org/sites/default/ files/materials/files/2016-09/AR_PornAndSV.pdf. Accessed 20 May 2020.

Johnson, Scott A. »The Role of Pornography in Sexual Offenses: Information for Law Enforcement and Forensic Psychologists.« International Journal of Emergency Mental Health and human Resilience, vol. 7, no. 1, 2015, pp. 239-42.

Joraschky, Peter. »Sexueller Mißbrauch und Vernachlässigung in Familien.« Sexueller Mißbrauch, Mißhandlung, Vernachlässigung, edited by Urlich Tiber Egle, Sven Olaf Hoffmann, Peter Joraschky, Schattauer, 1997, pp. 79-92.

Klasnić, Ksenija, and Aleksandar Štulhofer. »Prihvaćanje mitova o silovanju među adolescentima: longitudinalna medijska studija.« Društvena istraživanja, vol. 27, no. 2, 2018, pp. 221-42.

Kuby, Gabriele. Svjetska seksualna revolucija. Uništenje slobode u ime slobode. Naklada Benedikta, 2013.

Kurst-Swanger, Karel, and Jacqueline L. Petcosky. Violence in the Home. Multidisciplinary Perspectives. Oxford University Press, 2003.

Landripet, Ivan. »Testing the Influence of Pornography on Sexual Violence in Croatia: The Public Crime Statistics Approach.« Društvena istraživanja, vol. 16, no. 1-2, 2007, pp. 269-93.

Loseke, Donileen R., et al., editors, Current Controversies on Family Violence, Sage Publications, Thousand Oaks, 2005.

MacKinnon, Catharine A. »Pornography as Sex Discrimination. $\ll$ Rape and Society, edited by Patricia Searles and Ronald J. Berger, Boulder, Westview, 1995, pp. 99-105. 
Malamuth, Neil M., et al. »Pornography and Sexual Aggression: Are There Reliable Effects and Can We Understand Them? «. Annulal Review of Sex Research, vol. 11, 2000, pp. 26-91.

McCue, Margi Laird. Domestic Violence. A Reference Handbook, 2nd ed., ABC-CLIO, 2008.

Mehta, Michael D. »Sex Online: Regulation and Pornography Surveillance in the Wired World.« Digital democracy. Policy and Politics in the Wired World, edited by Cynthia J. Alexsander, and Leslie A. Pal, Panliber, 2001, pp. 177-190.

Muraro, Giordano. »Pornografia.« Nuovo Dizionario di Bioetica, edited by Salvino Leone, and Salvatore Privitera, Città Nuova Editrice. Istituto Siciliano di Bioetica, 2004, pp. 877-880.

Pontificio Consiglio delle Comunicazioni sociali, Pornografia e violenza nei mezzi di comunicazione: Una Risposta Pastorale, available at: www.vatican.va/roman_curia/pontifical councils /pccs/documents/rc _pc _ pccs_doc_04101989_criteria_it.html. Accessed 24 March 2020.

Siann, Gerda. Gender, Sex and Sexuality. Contemporary Psychological Perspectives. Taylor \& Francis, 1994.

Stella, Renato. $\gg$ Il fenomeno di difusione di massa della pornografia. « Aggiornamenti sociali, vol. 43, no. 3, 1992, pp. 213-226.

Strossen, Nadine. Difesa della pornografia. Le nuove tesi radicali del femminismo americano. Castelvecchi, 1995.

Šolić, Petar. »Fenomenološki pristup pornografiji.« Crkva u svijetu, vol. 26, no. 1, 1991, pp. 57-73.

Štulhofer, Aleksandar, et al. »Rizici pornografije? Empirijsko testiranje uvriježenih predodžbi o konzumentima seksualno eksplicitnih sadržaja.« Revija za sociologiju, vol. 34, no. 1/2, 2003, pp. 75-96.

World Health Organization (WHO). »Understanding and Addressing Violence against Women.« www.apps.who.int/iris/bitstream/handle/10665/77434/WHO_RHR_12.37 eng.pdf;jsessionid $=63 B F 0 C$ 72837E865D76816FF57674443C ?sequence $=1 . \overline{\text { Accessed }}$ 2 July 2020.

Wright, Paul J., et al. »A Meta-Analysis of Pornography Consumption and Actual Acts of Sexual Agression in General Population Studies.« Journal of Communication, no. 66, 2016, pp. 183-205.

Žilić, Marija, and Josip Janković. »Violence.« Social Topics: Journal of Social Work and Related Sciences, vol. 1, no. 3, 2016, pp. 67-87. 


\title{
O PORNOGRAFIJI I NJEZINU UTJECAJU NA SEKSUALNO NASILJE
}

\author{
Šimun BILOKAPIĆ* - Ana JELIČIĆ**
}

\begin{abstract}
Sažetak: Nakon kratke prezentacije fenomena pornografije, osobito njegove uobičajene, ali zloslutne prisutnosti u sredstvima društvenoga priopćavanja, članak se usredotočuje na analizu odnosa izmedu pornografije i seksualnoga nasilja. U clanku se na temelju teorija o obiteljskom nasilju i osobito teorija o seksualnom nasilju propituje povezanost pornografije i seksualnoga nasilja, analiziraju se suprotna stajališta o njihovu meduodnosu te eventualni interesi koji stoje u pozadini različitih stajališta. Slijedi potom pomna analiza dokumenta Papinskoga vijeća za komunikacije naslovljenoga »Pornografija $i$ nasilje u sredstvima komunikacije « te antropološka i etička analiza odnosa pornografije $i$ seksualnoga nasilja. Prijetvornost $i$ prijevarnost dvojbe sastoji se u činjenici, zaključak je članka, da pornografija i seksualno nasilje nisu samo u uzročno-posljedičnoj svezi, nego da su to dva vrlo slična fenomena, gotovo isti po svojoj naravi i sadržaju, da su posljedica istoga mentaliteta $i$ kulture, s istim devastirajućim učincima na ljudsku osobu i njezinu spolnost.
\end{abstract}

Ključne riječi: pornografija, (seksualno) nasilje, ovisnost, internet, antropologija, etika.

* Doc. dr. sc. Šimun Bilokapić, Katolički bogoslovni fakultet, Sveučilište u Splitu, Zrinsko-frankopanska 19, 21000 Split, Hrvatska, simun.bilokapic@st.t-com.hr

** Doc. dr. sc. Ana Jeličić, Sveučilišni odjel za forenzične znanosti, Sveučilište u Splitu, Ruđera Boškovića 33, 21000 Split, Hrvatska, anjelici08@gmail.com 